\title{
The Influences of Capital Structure, Company Growth, Profitability, and Company Sizes on Profit Management
}

\author{
Fathihani ${ }^{1}$ \\ \{fathihani@undira.ac.id $\left.{ }^{1}\right\}$
}

Management Departement, Dian Nusantara University, West Jakarta, DKI Jakarta, Indonesia ${ }^{1}$

\begin{abstract}
This research is supposed to test and analyze the influence of capital structure, growth, profitability, and company size on profit management in mining companies which listed on the Indonesian Stock Exchange in 2016-2018 period both partially and simultaneously. The design of this research is using causal type research with quantitative methode. The sampling of this research is using the purposive sampling which is included in the mining sector which listed on the Indonesian Stock Exchange in 2016-2018 period. The analytical method of this research is using multiple linear regressions. The result of this research are The Capital Structure variable has no significant effect on the Profit Management variable, The Growth variable has significant effect on the Profit Management variable, The Profitability variable has no significant effect on the Profit Management variable, The Company Size variable has no significant effect on the Profit Management variable. The variables of Capital Structure, Growth, Profitability, and Company Size simultaneously have significant on the Profit Management variable.
\end{abstract}

Keywords: Capital Structure, Growth, Profitability, Company Size and Profit Management.

\section{Introduction}

Financial Statements have the components information of a company which should have be published to some parties who need all forms of accountability for the management performance of the company. Financial Statements have many benefit for its users, however what gets more attention from financial statements is the profit information. Even though sometimes the financial statements information doesn't describe the actual condition of those companies performances, this is due to their profit management practices that carried out by those companies management. The profit informationthat have been submitted is the actual results, not just a manipulation. The profit informationis expected to be the guidelines for the shareholders and the other users. The importance of profit informationof some companies made some management's side have to manipulating the actual profit information. This is intended to attract investorsto invest their shares in the company.Earnings information is a component of the report corporate finance that aims to assess management performance, helps estimating the ability of representative earnings in the long run, and estimating risk investation $[1]$.

Company's financial performance which is currently unstable will encourage their management to practice profit management. Profit management is the condition where the management intervenes in the process of preparing financial statements for external parties so that they can flatten, increase, and decrease those profits [2]. Profit management is a special topic in accounting theory and the main impact of profit management practices can lead to 
bias in financial statements. Besides that, except influencing accounting profits, it can also influence stakeholders in their decision making [3].

Profit management actions have led to several widely known cases of accounting statement scandals. Many cases of those have a detrimental impact on many parties, including creditors and investors [4]. The cases regarding alleged earnings management practices at a mining company, namely Indonesia Corruption Watch (ICW), which reported the alleged manipulation of reporting sales of three coal mining companies owned by the Bakrie Group to the Directorate of General Tax. ICW suspects the reporting engineering carried out by PT BumiRresourcesTbk. and subsidiaries which caused the state losses of US \$ 620.49 million. ICW calculation results using various primary data including financial statements audit shows that their sales report for 2003-2008 was US \$ 1.06 billion lower than the actual amount. As a result, during this time the state losses were estimated lack of revenue.

A similar case was also carried out by PT. (TimahPersero), back when 2015 manipulated its financial statements in semester 1-2015. PT Timah made a statement that the company experienced a positive performance. It's Chairman, Ali Samsuri, revealed that PT Timah's financial condition has been unhealthy for the past three years. The inability of the Board of Directors of it to come out of the trap of loss has resulted in surrender of $80 \%$ of it's mining area to business partners. When referring to the real conditions that occur on it, Ali believes that the financial statements of the first semester of 2015 PT TimahTbk are fictitious. According to him, in the first half of 2015 PT Timah's operating profit had lost IDR 59 billion. In addition to experiencing a decline in profits, PT Timah also recorded an increase in debt of almost 100 percent compared to 2013. In 2013, the company's debt only reached Rp263 billion. However, this amount of debt increased to IDR 2.3 trillion in 2015.

Based on research background. The formulation of the problem in this study is:How Capital Structure, Growth, Profitability, Company Size affect management in mining companies listed on the IDX for the 2016-2018 period. How does the effect of capital structure on earnings management. How does growth affect earnings management? How does profitability affect earnings management? How does company size affect earnings management?

\section{Literature Review}

\subsection{Agency Theory}

The concept of Agency Theory is a relationship or contract between the principal and agent, where the principal is the party who employs the agent to perform tasks for the interests of the principal, while the agent is the party who carries out the interests of the principal.Thus, agency problems can arise when one parts (the 'principals') contracts with another part (the 'agents') to make decisions on behalf of the principals [5].

\subsection{Earning Management}

The concept of earnings managementis management's choice of accounting policies or tangible actions that affect earnings in order to achieve several earnings goals to be reported.Earnings management is often used by the management and insiders, as well as the controlling shareholders, to expropriate the costs of the other stakeholders [6].

\subsection{Capital Structure}


Capital Structure is a combination of debt, preferred stock and common equity which will be the basis for capital raising by the company [7]. Capital Structure (DER) is a proportion in determining the fulfillment of a company expenditure needs where the funds obtained are using some combinations or some sources from long term funds which from inside and outside of the company.[8]

\subsection{Growth}

Growth is the change (decrease or increase) in total assets owned by the company.[9] Assetgrowth is calculated as the percentage change in assets at a certain time against the previous year. Growth is the change in total assets, either in the form of increase or decrease, experienced by a company during one period (one year). Growth can be defined as an increase in a company. [10]The higher the company's growth, which also means that the higher the company's growth opportunities, the greater the need for funds needed. Companies that have a fast growth rate tend to use a source of funds in the form of debt rather than issuing equity $[11]$.

\subsection{Profitability}

Profitability is the company's ability to make profits and measure the level of operational efficiency and using its assets efficiency [12]. Profitability is an indicator to assess the company's financial performance or ability to generate profits. Profitability ratiosmeasure the income or operating success of a company for a given period of time [13].

\subsection{Company Size}

Sizeof the company determined from the total assets owned by the company. Company size is the amount of assets owned by a company. [14] Company size is a scale where the size of the company can be classified according to various ways, including total assets, log size, stock market value, and others. [15]

\section{Methods}

The approach of this research is using a quantitative approach and based on its purpose, this type of research is causal, namely research that explains the effect of an independent variable on the dependent variable. The independent variables in this research include capital structure, growth, profitability and company size and for the dependent variable in this study is profit management. The framework in this research can be clearly illustrated in the image below. 


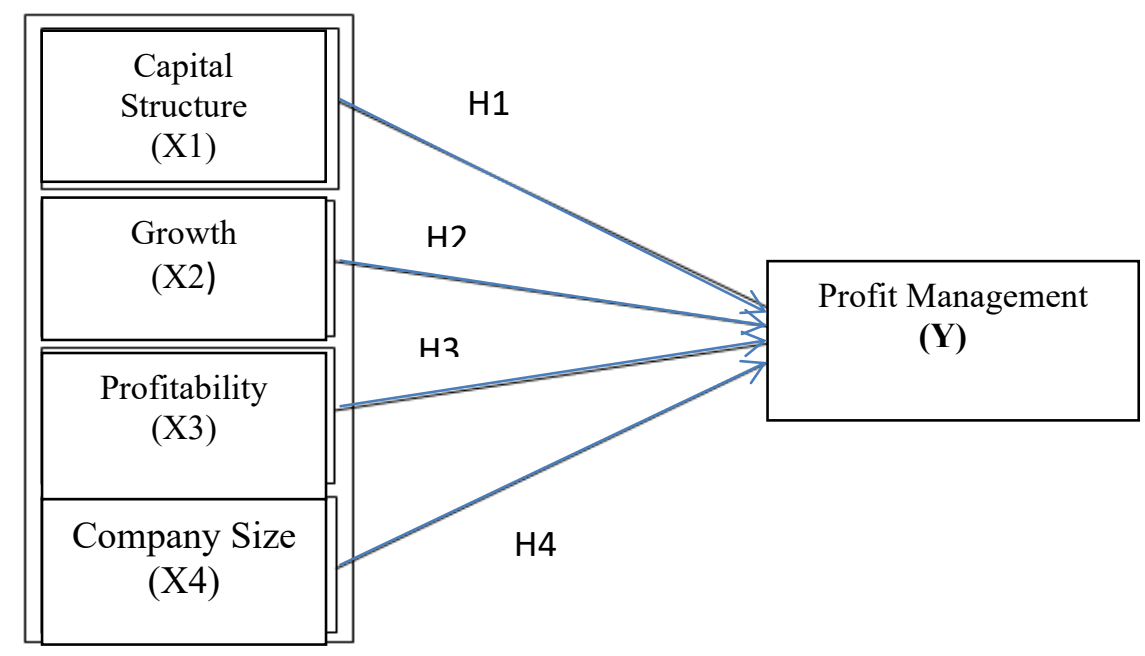

Figure 1. Image of the Framework

The population of this research is all companies included in the Mining Sector which are listed on the Indonesia Stock Exchange until 2018 which are 40 companies. The sampling of this research will using the purposive sampling which is part of the non-probability sampling method. This sampling chooses a specific target group to obtain information. The sample is set for certain types of groups that can provide the information needed, because the group is the only party that has the information or because the group is in accordance with the criteria set by researchers. Considerations or criteria for determining the sample in this study, which are :

1. Public companies in the Indonesia Stock Exchange registered mining sector for the period of 2016-2018.

2. Companies that publish annual reports for the period 31 December 2016-2018.

3. Companies whose shares are active in the 2016-2018 period.

Table 1. The Definition Operational Variable

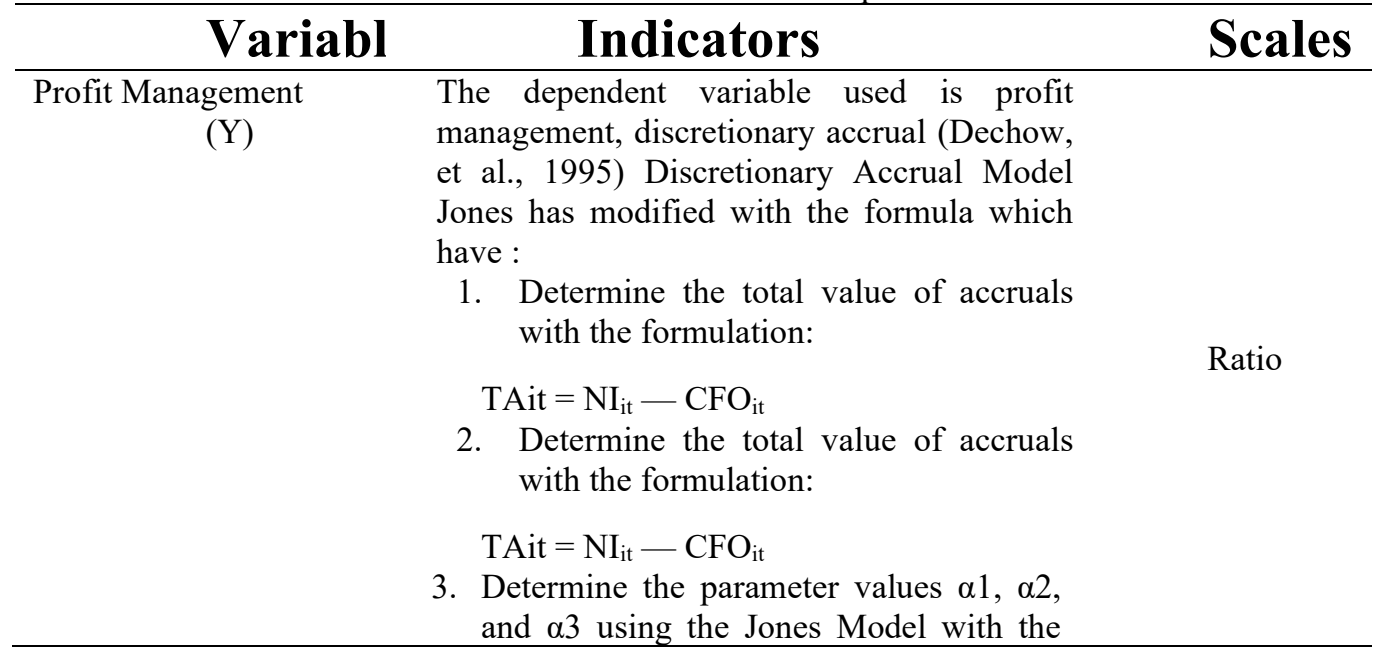




\begin{tabular}{|c|c|c|}
\hline Variabl & Indicators & Scales \\
\hline & $\begin{array}{l}\text { formulation: } \\
\text { TAit }=\alpha_{1}+\alpha_{2} \mathrm{ARev}_{\mathrm{it}}+\alpha_{3} \mathrm{PPE}_{\mathrm{it}}+\varepsilon_{\mathrm{it}} \\
\text { Then to scale the data, all of these } \\
\text { variables are divided by the assets of the } \\
\text { previous year( }\left(\mathrm{A}_{\mathrm{it}-1}\right) \\
\mathrm{TA}_{\mathrm{it}} / \mathrm{A}_{\mathrm{it}-1}=\alpha_{1}\left(1 / \mathrm{A}_{\mathrm{it}-1}\right)+\alpha_{2}\left(\operatorname{Rev}_{\mathrm{it}} / \mathrm{A}_{\mathrm{it}-1}\right)+ \\
\alpha_{3}\left(\mathrm{PPE}_{\mathrm{it}} / \mathrm{A}_{\mathrm{it}-1}\right)+\varepsilon_{\mathrm{it}} \\
\text { 4. Calculate the NDA value with the } \\
\text { formulation: } \\
\text { NDAit }=\alpha_{1}\left(1 / \mathrm{A}_{\mathrm{it}-1}\right)+\alpha_{2}\left(\operatorname{Rev}_{\mathrm{it}} / \mathrm{A}_{\mathrm{it}-1}-\right. \\
\left.\text { Recit } / \mathrm{A}_{\mathrm{it}-1}\right)+\alpha_{3}\left(\mathrm{PPE}_{\mathrm{it}} / \mathrm{A}_{\mathrm{it}-1}\right) \\
\text { 5. Determine the value of discretionary } \\
\text { accruals by using the formulation: } \\
\text { DA } \mathrm{A}_{\mathrm{it}}=\mathrm{TA}_{\mathrm{it}} / \mathrm{A}_{\mathrm{it}-1}-\mathrm{NDA}_{\mathrm{it}}\end{array}$ & \\
\hline $\begin{array}{l}\text { Debt to Equity (DER) } \\
\left(\mathrm{X}_{1}\right)\end{array}$ & $\mathrm{DER}=\frac{\text { Total Liquidity }}{\text { Total Equity }}$ & Ratio \\
\hline $\begin{array}{l}\text { Growth } \\
\left(\mathrm{X}_{2}\right)\end{array}$ & Growth $=\frac{\text { Asset }_{t i}-\text { Asset }_{t i-1}}{\text { Asset }_{t i-1}}$ & Ratio \\
\hline $\begin{array}{l}\text { Profitability } \\
\left(\mathrm{X}_{3}\right)\end{array}$ & ROA $=$ Net Profit $/$ Total Asset & Ratio \\
\hline $\begin{array}{l}\text { Company Size } \\
\left(\mathrm{X}_{4}\right)\end{array}$ & Natural logarithm of total asset & Ratio \\
\hline
\end{tabular}

\section{Result and Discussion}

\subsection{The Selection of RegressionModel}

There are 3 regression models in this study, namely CEM, FEM, and REM. The first step that must be done is to choose which model is the best among the three models, namely by means of the Chow test, the Hausman test, and the Lagrange Multiplier test. After processing the data, it was decided that the best regression model was to use the Random Effect Model. With the following equation model are:

Profit Management $=-3.13 \mathrm{E}+08+8686334 \mathrm{Capital}$ Structure $-8.87 \mathrm{E}+08$ Growth 4114846 Profitability - 13964984 Company Size + e

The explanation in the regression model formed above is:

a. The constants of $-3.13 \mathrm{E}+08$, shows that if there is no effect from the variable $\mathrm{x}$ yaituCapital Structure, Growth, Profitability, Company Size then the Profit Management is $-3.13 \mathrm{E}+08$.

b. Regressioncoefficient x1 (Capital Structure) is amounted 8686334, shows that when $\mathrm{x} 1$ increasing asmuch as 8686334 then it will add the value of Profit Management as much as 8686334 . So, the coefficient obtained is positive, which means that if there is a decrease in $\mathrm{X} 1$, there will be a decrease in $\mathrm{Y}$ and vice versa, or in the same direction. 
c. Regressioncoefficient X2 (Growth) is amounted $-8.87 \mathrm{E}+08$, shows that when X2 decreasingas much as $8.87 \mathrm{E}+08$ then it will add the value of Profit Management as much as $8.87 \mathrm{E}+08$. So, the coefficient obtained is negative, which means that if there is a decrease in $\mathrm{X} 2$, there will be anincrease in $\mathrm{Y}$ and vice versa, or in the same direction.

d. Regressioncoefficient X3 (Profitability) is amounted -4114846 , shows that when X3 decreasingasasmuch as 4114846 then it will add the value of Profit Management as much as 4114846 . So, the coefficient obtained is negative, which means that if there is a decrease in $\mathrm{X} 3$, there will be anincrease in $\mathrm{Y}$ and vice versa, or in the same direction.

e. Regressioncoefficient X4 (Company Size) is amounted -13964984, shows that when $\mathrm{X} 4$ decreasingasmuch as 13964984 then it will add the value of ROA as much as 13964984. So, the coefficient obtained is negative, which means that if there is a decrease in $\mathrm{X} 4$, there will be anincrease in $\mathrm{Y}$ and vice versa, or in the same direction.

Table 2. Multicollinearity Test

\section{DER GROWTH ROA SIZE}

\begin{tabular}{lrrrr}
\hline \hline Capital_Structure & 1.000000 & 0.124440 & -0.037472 & 0.029545 \\
Growth & 0.124440 & 1.000000 & 0.006886 & -0.099643 \\
Profitability & -0.037472 & 0.006886 & 1.000000 & 0.193192 \\
Size & 0.029545 & -0.099643 & 0.193192 & 1.000000
\end{tabular}

Based on above, it can be seen that there is no relation coefficient (R2) whose value is more than 0.80 . The coefficient values are $0.124440,-0.037472,0.029545,0.006886$, $0.099643,0.193192$. Then it can be concluded that the data does not occur multicollinearity.

Table 3. Heteroscedastic Test

\begin{tabular}{ll}
\hline \hline Variable & Prob. \\
\hline \hline Capital_Structure & 0.7770 \\
Growth & 0.0600 \\
Profitability & 0.4978 \\
Size & 0.1071 \\
\hline \hline
\end{tabular}

Based on above, it can be seen that the prob value of the Capital Structure, Growth, Profitability and Size variables are respectively $0.7770,0.0600,0.4978,0.1071$. All the prob values there are no value below 0.05 which means it can be concluded that there is not occur heteroscedastic.

Table 4. Regression Coefficient

$$
\text { Adjusted R-squared } \quad 0.199694
$$


Based on the table 4, it can be seen that the coefficient of determination is 0.199694 or equal to $19.9694 \%$ meaning that the variable Capital Structure, Growth, Profitability, and Size simultaneously affect the Profit Management of $19.9694 \%$ and the rest is influenced by other variables or factors beyond this research.

Table 5. The F Test

\begin{tabular}{ll}
\hline \hline F-statistic & 4.680451 \\
Prob(F-statistic) & 0.002531 \\
\hline \hline
\end{tabular}

Based on the table 5, the Prob (F-Statistic) value is 0.002531 where the number is less than or smaller than the significance level of 0.05 , it can be concluded that the variable Capital Structure, Growth, Profitability and Firm Size simultaneously have significant effect on the variable Profit Management.

Table 6. The t Test

\begin{tabular}{lllll}
\hline \hline Variable & Coefficient & Std. Error & t-Statistic & Prob. \\
\hline \hline C & $-3.13 \mathrm{E}+08$ & $2.85 \mathrm{E}+08$ & -1.095276 & 0.2782 \\
Capital_Structure & 8686334. & 9255707. & 0.938484 & 0.3521 \\
Growth & $-8.87 \mathrm{E}+08$ & $2.09 \mathrm{E}+08$ & -4.236274 & 0.0001 \\
Profitability & 4114846. & 6524338. & 0.630692 & 0.5309 \\
Size & 13964984 & 14448041 & 0.966566 & 0.3380 \\
\hline \hline
\end{tabular}

Based on the table 6, the prob values for the Capital Structure, Growth, Profitability, and Size variables are $0.3521,0.0001,0.5309,0.3380$ then it can be explained that :

a. The Capital Structure variable has a Prob value of 0.3521 which the value is bigger than the significance value of 0.05 so it can be concluded that the Capital Structure variable has no significant effect on the Profit Management variable.This is in accordance with the theory which states that capital structure has an influence on Profit Management, but there are differences where in their research it has a significant effect while in this study it has an insignificant effect. (14) The greater the leverage ratio, the greater the level of dependence of the company on external parties (creditors) and the greater the burden of debt costs (interest costs) that must be paid by the company. Based on this research, it states that there is the same direction between capital structure and earnings management, this means that the higher the leverage ratio, the greater the manager's ability to manage earnings because the company is threatened with not being able to pay interest costs that must be paid or default.

b. Growth variable has a Prob value of 0.0001 where the value is smaller than the significance value of 0.05 so it can be concluded that the Growth variable has a significant effect on the Profit Management variable.This is in accordance with the results of research which state that growth has a significant effect on earnings management. If you look at the negative direction of the growth variable on the earnings management variable, it means that every decrease in the growth variable will increase the earnings management variable. (15) Low growth will reflect poor company performance, so by carrying out earnings management it is hoped that the company will 
continue to receive funds from investors and will continue to grow. When viewed from the research results that show the opposite direction between growth and earnings management, it can be concluded that the smaller the growth, the greater the likelihood of managers doing earnings management and the greater the value of growth, the smaller the managers to do earnings management.

c. Profitability variable has a Prob value of 0.5309 where the value is greater than the significance value of 0.05 so it can be concluded that the Profitability variable has no significant effect on the Profit Management variable.This is in accordance with what was stated that profitability has an effect on earnings management, although there are differences in research that has a significant effect while in this study it is not significant. [16] If you look at the direction of the results of this study, it can be seen that the direction is negative or opposite between the profitability variable and the earnings management variable. It can be concluded that the smaller the profitability value, the higher the chances of managers doing earnings management, this is done to improve the performance of a manager so that looks good in managing and producing the company. meanwhile, the higher the profitability value, the less likely the manager is to carry out earnings management.

d. Company Size variable has a Prob value of 0.3380 where the value is greater than the significance value of 0.05 so it can be concluded that the Size variable has no significant effect on the Profit Management variable.This is in accordance with the results of research which in their research stated that the firm size variable has an influence on the earnings management variable, although there are differences in research have a significant effect while in this study states that the effect is not significant. When viewed from the opposite direction, the greater the Company Size, the less likely it is for managers to practice earnings management.[17] This is done because in large companies it will get more attention from shareholders, investors and the public so that there is less incentive to do earnings management. And vice versa, the smaller the size of the company, the greater the likelihood of managers doing earnings management.

e. The variables of capital structure, growth, profitability, company size simultaneously have a significant effect on earnings management variables

\section{Conclusions}

Based on the results above, the conclusions that can be drawn from this research are as follows: Capital Structure variable have no significant effect on Profit Management variable, Growth variable have a significant influence on Profit Management variable, Profitability variable has no significant effect on the Profit Management variable, the variable size of the company has no significant effect on the Profit Management variable, thus both capital structure, growth, profitability, company size simultaneously have a significant effect on the Profit Management variable.

Some suggestions that researchers can convey based on the results are: for investors who want to invest their funds in the company both be more careful and cautious whether the company plays a high profit management practice or not, in order to obtain profits in accordance with expectations. For further researchers, the research indicators can be replaced with other proxies or by adding other variables in order to obtain better results. This research can also be developed by trying on other sectors or subsectors and or adding more complete research periods, methods and test equipment. 


\section{References}

[1] M. A. Tahir, E. Puspitosarie, and P. Book, "The Analysis of Earning management and Earning Response Coefficient: Empirical Evidence from Manufacturing Companies Listed in Indonesian Stock Exchange," vol. 3, no. 8, pp. 41-54, 2014.

[2] M. Ahmadiand, I. S. Arasi, and M. Garajafary, "Studying the relationship between working capital management and profitability at tehran stock exchange: A case study of food industry," Res. J. Appl. Sci. Eng. Technol., vol. 4, no. 13, pp. 1868-1874, 2012.

[3] E. Indracahya and D. A. Faisol, "The Effect of Good Corporate Governance Elemets, Leverage, Firm Age, Company Size and Profitability On Earning Management (Empirical Study Of Manufacturing Companis inn BEI 2014-2016)," Profita, vol. 10, no. 2, pp. 203-227, 2017.

[4] E. A. Patrick, E. C. Paulinus, and A. N. Nympha, "The Influence of Corporate Governance on Earnings Management Practices: A Study of Some Selected Quoted Companies in Nigeria," vol. 1, no. 5, pp. 482-493, 2015.

[5] K. Minnick, "The role of corporate governance in the write-off decision," Rev. Financ. Econ., vol. 20, no. 4, pp. 130-145, 2011.

[6] Yuanita, Missy, Budiyanto, and S. Riyadi, "Influence of Capital Structure, Size and Growth on Profitability and Corporate Value," Int. J. Bus. Financ. Manag. Res., vol. 4, pp. 80-101, 2016.

[7] K. Ntoiti, "Effect of Capital Structure on Financial Performance of Listed Commercial Banks in Kenya. a Case Study of Kenya Commercial Bank Limited," Jomo Kenyatta Univ. Agric. Technol., vol. 2, no. 72, pp. 750-781, 2015.

[8] A. Chowdhury and S. P. Chowdhury, "10_V3_BEH_BANGLADESH_AnupChowhury_ et al d ac.pdf," Bus. Econ. Horizons, vol. 3, no. 3, pp. 111-122, 2010.

[9] U. Ali, M. Noor, M. K. Khurshid, and A. Mahmood, "Impact of Firm Size on Earnings Management: A Study of Textile Sector of Pakistan," SSRN Electron. J., vol. 7, no. 28, pp. 4756, 2015.

[10] Z. An, D. Li, and J. Yu, "Earnings management, capital structure, and the role of institutional environments," J. Bank. Financ., vol. 68, pp. 131-152, 2016.

[11] F. Rezaei and M. Roshani, "Efficient or opportunistic earnings management with regards to the role of firm size and corporate governance practices," Interdiscip. J. Contemp. Res. Bus., vol. 3, no. 9, pp. 1312-1322, 2012.

[12] D. L. T. S. Dwi Lusi Tyasing Swastika, "Corporate Governance, Firm Size, and Earning Management: Evidence in Indonesia Stock Exchange,” IOSR J. Bus. Manag., vol. 10, no. 4, pp. 77-82, 2013.

[13] N. Tabassum, A. Kaleem, and M. S. Nazir, "Real Earnings Management and Future Performance," Glob. Bus. Rev., vol. 16, no. 1, pp. 21-34, 2015.

[14] M. Scharfstein and Gaurf, “済無No Title No Title,” J. Chem. Inf. Model., vol. 53, no. 9, pp. 1689-1699, 2013.

[15] M. W. Birru, "The Impact of Caiptal Structure on Financial Performance of Commercial Banks in Ethiopia," Glob. J. Manag. Bus. Res. C Financ., vol. 16, no. 8, pp. 42-52, 2016.

[16] L. G. Eldenburg, H. A. Krishnan, and R. Krishnan, Management Accounting and Control in the Hospital Industry: A Review, vol. 6, no. 1. 2017.

[17] S. Oktavani and Devie, "Pengaruh Earnings Management terhadap Firm Value melalui Financial Performance sebagai variabel intervening pada perusahaan yang terdaftar di LQ 45 value through financial performance as an intervening variable . Earnings management measured by using disc," Bus. Account. Rev., vol. 5, no. 2, pp. 25-34, 2017. 